\title{
An Interaction between Firm Strategy, Capital Structure and Firm's Performance
}

\author{
Suresh Ramakrishnan, Agha Amad Nabi, *Saqib Muneer, Melati Ahmad Anuar \\ Faculty of Management, Universiti Teknologi Malaysia, Malaysia \\ *saqibmuneer85@gmail.com
}

\begin{abstract}
The study tries to determine the association among corporate strategy, social structure and firm performance. In this regard, the monetary reports of 78 companies listed in Karachi Stock Exchange since 2007 to 2014 were scrutinized. In this research, firm strategy (sales growth, liquidity) and capital structure (debt ratio) were used as sovereign variables, and firm performance (return on equity, return on assets, free cash flow for the firm, free cash flow per share) were functional and are used as dependent variables, so to study the affiliation between corporate strategy, capital structure and firm performance within a 8-years period from 2007 to 2014. Secondary data has been used to test the hypotheses; single variable linear regression method was used and their significance was evaluated using Statistics T (t-test) and F (Fisher). The study results indicate that there is a significant positive relationship between sales growth variables and two types (among four types) of performance criteria in the study, namely return on equity and return on assets. And there is a positive significant relationship between firm liquidity and three criteria of firm's performance in the study namely return on equity, free cash flow per share and return on assets. Also, debt ratio has a positive significant relationship with free cash flow for firm and a negative significant relationship with return on assets.
\end{abstract}

Keywords: Capital Structure, Corporate Strategy, Liquidity, Firm Performance, Free Cash Flow for Firm

\section{Introduction}

Firms to develop and grow require financial resources, and decision making regarding using different financial resources and determining a sufficient capital structure which maximize stockholders wealth is considered as a one of the most significant issues encountered by managers. Nowadays, credit rating of firms depends largely on its capital structure, and in fact the basis for the production and the delivery of service depend mainly upon supplying and using funds (Mires et al., 2001). Notably, the social structure of each firm is an initial precaution in connection with its financial problems, and in corporate strategic planning, it is necessary to determine the factors influencing the efficacy of their financing. Firms nowadays work in an increasingly developing and competitive environment. To survive, they are forced to deal with many national and international competing factors and to develop their activities through new investments. The significance of capital structure attracted more attention since the studies conducted by Modigliani and Miller (1958). They believed that there is no difference between financing through return on equity and debt considering firm value. Therefore, different methods of financing have no extra value for firm, and there is no limitation for manager. But experimental evidences showed that the above issue does not practically exist and Modigliani and Miller (1961) indicated new results, and the significance of firms' social capital was determined more than before (Onaolapo \& Kajola, 2010). Key point for firm performance is firm strategy formula and executive decisions (Miller \& Rock, 1985). The present study attempts to investigate the relationship between firm performance by using two variables, namely corporate strategy (sales growth strategy and liquidity) and social capital.

\section{Literature Review}

Strategic thinking is considered an undeniable prerequisite to management in the third millennium. Increasingly changing and wonderful evolutions in all commercial and economic aspects indicate a taking privilege of a strategic thinking. To effectively formulate strategies, financial strengths and weaknesses of each firm must be determined. Liquidity, loan amount, flowing capital, profitability, efficient use of assets, cash flows and return on equity must be in a way that some strategies discarded. Regarding the effect of 
strategy on performance, it could be said that return on equity could be regarded as a linear function of assets growth, sales growth, growth potential and liquidity, which assets growth has the maximum effect on stockholders salary yield rate and sales growth, growth potential and liquidity has the minimum effect (Muneer et al., 2011). Whatever the recent strategic and financial performance of the company is better, a well-designed and well-executed strategy more likely exists. Weak strategic and financial performance is a sign of the existence of a weak strategy or inefficient administration of strategy or both of them (Khalili et al., 2011). Literature on strategic trends considers strategy from three aspects: descriptive approach, classification approach and adaptive approach (Manian et al., 2009).

Evolution of Strategy Paradigm: Phase 1: financial planning, Phase 2: planning based on prediction, Phase 3: planning based on external environment, Phase 4: strategic-phase management, Phase 5: strategic thinking

\section{Different Theories on Firm Capital Structure}

A. The theories associated with the choice between debt and equity

- traditional theory

- Modigliani and Miller Theorem

- The theory of the hierarchy of financing options 1

- Theory of Static equilibrium: A) representation theory B) firm control C) debt tax saving benefits and the expenses of its financial turmoil D) capital market timing

B. Theories associated with the choice between public and private debts

- information asymmetry theory

- debt representation costs

- re-negotiations

- management discretion

One criterion to select investment opportunities is firms' financial performance which is influenced by different factors. One of the most significant motivations of investors to enter capital market is to achieve an appropriate yield and consequently increase in the wealth of stockholders (Muneer et al., 2012). The success of corporate strategies can be reflected in its performance and firm performance could be regarded as the firm success in creating values for different parts of market, but the performance of commercial firms is determined based on access to business objectives and using different units of such firms. In today's increasingly changing and complex environment, firms need to design and adapt strategies that enable them to improve increasingly their performance. Because in such an environment, the firms are able to survive that maintain their proactive and match with dynamic and variable situation of today's competitive market (Kaplan \& Norton, 1996; Muneer \& Rehman, 2012). Studying the performance of Pakistani firms, it is possible to observe varying and controversial trend of the growth and rate of return on investment over the ten past years. Meanwhile, experts consider the potential of the present firms in Pakistan capital market in terms of performance higher than its reported rate. In fact, the main obstacle to improve the performance of firms is the selection of the most efficient and optimal strategy considering organization features, which such strategies has been reported as the most significant challenge to recent investigations and studies (Saeed, 2009: Muneer et al., 2013).

The results from studies conducted have led to following four approaches regarding performance criteria"

- Accounting approach: in this approach, the values included in financial statements such as profit, profit per share, operational cash flows, return on assets and return on equity to evaluate performance are used (Rajatavanin, R., \& Venkatesh, 2007).

- Economic approach: based on this approach in which economic concepts are used, the performance of commercial unit is evaluated by underlining profitability, firm assets and considering return rate and capital cost rate (Anvari et al., 2003). Economic value added, modified economic value added and market value added are categorized in this group.

- Integrated approach: in this approach, a combination of accounting and market information to evaluate performance is applied such as Tobin s q ratio and price/earnings ratio (Malekian and Asgari, 2006). 
- Financial management approach: according to this approach, financial management theories such as Capital Assets Price Making Pattern (CAPM) and concepts such as risk and return are predominantly used. The approach mainly focuses on extra yield in each share (Rajatavanin \& Venkatesh, 2007).

Li et al. (2009) conducted a study on capital structure. In a part of this study, ROA (return on asset) and ROS (return on sale) were used as criteria and it was concluded that there is a negative and agreeable relationship between financial performance and leverage and short time debts ratio. Therefore, Chinese firms less use short time debts. Hong tom Ong et al., (2011) concluded that liquidity strategies are not significantly related to firm performance. If managers attempt to consider firm performance, they must not waste their time to raise liquidity. Instead, they must focus on management and they concluded that capital structure influences overall performance of firms. Setaiesh \& Kashanipoor (2010) came to this conclusion that about $49 \%$ of the changes in firms' capital structure were influenced by variables such as equity cash benefit, profitability, business risk, assets structure, liquidity, the size and growth of firm. Among them, two variables, namely firms' liquidity and growth had negative effect and other variables had positive effect on capital structure. Saeed (2009) came to this conclusion that about $95 \%$ of changes in capital structure are explained through rate of return on assets, firm size, market value to book value of return on equity, net assets, machinery and equipment, and standards of Corporate Governance System.

\section{Methodology}

The study statistical community is composed of the companies listed in Karachi Stock Exchange. The study statistical sample includes financial information of exchange stock firms since 2007-2014 which using a series of sample conditions, 78 firms were selected in 8 years, among firms listed on Karachi Stock Exchange.

\section{Data Collection}

- Information on research literature and theoretical basics are collected using a library-based method and compiled from Persian and English books and foreign specialized magazines

- Information in the second section is related to the firms listed in Karachi Stock Exchange which their financial information and relevant explanatory notes from 2007 to 2014 must have been provided and we collected them from Karachi Stock Exchange website.

Data analysis: In the present study, SPSS software was used to analyze data and to assess the effects of variables, single variable and correlative and linear regression statistical tests was applied.

Descriptive Statistics: in this method, some tables are presented and descriptive statistics measures such as central and scattering indices are applied to describe the study data, in turn, the issue becomes more transparent.

Calculating Central Indices: In this study, given that the measurement scale is quantitative, average is used. In addition, the maximum and minimum values of variables are determined in this stage.

Calculating scattering indices: scattering indices are different from central indices. They show the amount of scattering or changes between data of a distribution. In the present study, standard deviation is used. Table 1 shows the results from central and scattering indices. 
Table 1: The Study Data Descriptive Analysis

\begin{tabular}{lrrrrrr}
\hline Variable & Abbreviation & $\begin{array}{c}\text { The number of } \\
\text { Observations }\end{array}$ & Mean & $\begin{array}{c}\text { Standard } \\
\text { Deviation }\end{array}$ & Minimum & Maximum \\
\hline Return On Assets & ROA & 610 & $0 / 159$ & $0 / 103$ & $0 / 011$ & $0 / 54$ \\
Return on Equity & ROE & 610 & $0 / 423$ & $0 / 231$ & $0 / 006$ & $1 / 47$ \\
Liquidity & LI & 610 & $0 / 064$ & $0 / 071$ & $0 / 002$ & $0 / 57$ \\
Sales Growth & SG & 610 & $0 / 191$ & $0 / 240$ & $-0 / 59$ & $1 / 08$ \\
Free Cash Flow Per & FCFe & 610 & -316 & $110 / 11$ & $-464 / 39$ & $246 / 15$ \\
share & DR & 610 & $0 / 603$ & $0 / 194$ & $0 / 006$ & $0 / 91$ \\
Debt Ratio & FCFF & 610 & $0 / 154$ & $0 / 296$ & $-2 / 32$ & $1 / 181$ \\
Free Cash Flow for & & - & & & & \\
the Firm & & & & &
\end{tabular}

Based on the results from descriptive statistics including scattering and central indices, the standard deviation of most variables except for free cash flow per share was lower, which indicates that data has been scattered in a small area about the mean.

Inferential statistics: $1-3-4$ variables normality test: in this phase, Kolmogorov - Smirnov test is used to check whether the sample has been obtained from a population with a normal distribution or not.

Table 2: Results of Kolmogorov - Smirnov Test

\begin{tabular}{lrrr}
\hline Description & Abbreviation & Z Statistics & P-Value \\
\hline Return On Asset & ROA & $\mathbf{1} / \mathbf{1 3 0}$ & $\mathbf{0} / \mathbf{0 7 1}$ \\
Return On Equity & ROE & $\mathbf{1 / 1 0 1}$ & $\mathbf{0} / \mathbf{0 8 4}$ \\
Liquidity & LI & $\mathbf{3 / 8 1 8}$ & $\mathbf{0} / \mathbf{0 1 0}$ \\
Sales Growth & SG & $\mathbf{1} / \mathbf{0 7 0}$ & $\mathbf{0} / \mathbf{0 9 7}$ \\
Free Cash Flow Per Share & FCFe & $\mathbf{1} / \mathbf{0 7 3}$ & $\mathbf{0} / \mathbf{0 9 1}$ \\
Debt Ratio & DR & $\mathbf{2} / \mathbf{5 9 2}$ & $\mathbf{0} / \mathbf{0 0 1}$ \\
Free Cash Flow for the Firm & FCFF & $\mathbf{1 / 0 0 7}$ & $\mathbf{0} / \mathbf{0 9 2}$ \\
\hline
\end{tabular}

Table 3: Correlations between Variables

\begin{tabular}{|c|c|c|c|c|c|c|c|c|c|}
\hline Variable & $\begin{array}{l}\text { Abbreviati } \\
\text { on }\end{array}$ & ROA & ROE & LI & SG & FCFe & DR & FCFF & \\
\hline Return on Equity & ROE & $\begin{array}{l}0 / 000 \\
\text { sig }\end{array}$ & 1 & & & & & & \\
\hline & & $0 / 360$ & $0 / 144$ & & & & & & \\
\hline Liquidity & LI & $\begin{array}{l}0 / 000 \\
\text { sig }\end{array}$ & $\begin{array}{r}0 / 000 \\
\text { sig }\end{array}$ & 1 & & & & & \\
\hline & & $0 / 204$ & $0 / 202$ & $0 / 050$ & & & & & \\
\hline Sales Growth & SG & $\begin{array}{l}0 / 000 \\
\text { sig }\end{array}$ & $\begin{array}{r}0 / 000 \\
\text { sig }\end{array}$ & $\begin{array}{r}0 / 220 \\
\text { sig }\end{array}$ & 1 & & & & \\
\hline $\begin{array}{l}\text { Free Cash Flow } \\
\text { Per Share }\end{array}$ & FCFe & $\begin{array}{l}0 / 087 \\
0 / 033 \\
\text { sig }\end{array}$ & $\begin{array}{r}0 / 058 \\
0 / 156 \\
\text { sig }\end{array}$ & $\begin{array}{r}0 / 090 \\
0 / 048 \\
\text { sig }\end{array}$ & $\begin{array}{r}-0 / 041 \\
0 / 316 \\
\text { sig }\end{array}$ & 1 & & & \\
\hline Debt Ratio & DR & $\begin{array}{l}-0 / 317 \\
0 / 000 \\
\text { sig }\end{array}$ & $\begin{array}{r}0 / 070 \\
0 / 082 \\
\text { sig }\end{array}$ & $\begin{array}{r}-0 / 109 \\
0 / 087 \\
\text { sig }\end{array}$ & $\begin{array}{r}0 / 071 \\
0 / 071 \\
\text { sig }\end{array}$ & $\begin{array}{r}-0 / 016 \\
\text { sig } 0 / 702\end{array}$ & 1 & & \\
\hline $\begin{array}{l}\text { Free Cash Flow for } \\
\text { the Firm }\end{array}$ & FCFF & $\begin{array}{l}0 / 099 \\
0 / 014 \\
\text { sig }\end{array}$ & $\begin{array}{r}0 / 112 \\
0 / 006 \\
\text { sig }\end{array}$ & $\begin{array}{r}0 / 046 \\
0 / 260 \\
\text { sig }\end{array}$ & $\begin{array}{r}-0 / 016 \\
0 / 686 \\
\text { sig }\end{array}$ & $\begin{array}{r}0 / 564 \\
\text { sig } 0 / 000\end{array}$ & $\begin{array}{r}0 / 082 \\
0 / 043 \\
\text { sig }\end{array}$ & & 1 \\
\hline
\end{tabular}


The (K-S) test indicates that the study dependent variable scattering and also some independent variables follow a normal distribution.

In this study, in order to determining correlation between quantitative variables, Pearson correlation is used which the matrix of correlation between variables has been presented in Table 4. Based on the Pearson correlation coefficient between sales growth and return on equity which 0.202 at a significance level of 5\% and also sig in Table 000/0, it could be concluded that there is a significant relationship between sales growth and return on equity. The second secondary hypothesis in the study indicates that there is a relationship between sales growth and free cash flow per share. Based on the Pearson correlation coefficient between sales growth and free cash per equity which shows -0.041 in the significance level $5 \%$, it could be concluded that there is a negative relationship between sales growth and free cash flow per equity, but according to sig in Table 3 which is 0.316 , such conclusion cannot be obtained. All the hypotheses are interpreted as above.

Hypotheses Testing Results: In this part, based on the study hypotheses which are composed of main and secondary hypotheses, the hypotheses are tested. There is a relationship between sales growth and firm performance. To test the first hypothesis, eight secondary hypotheses have been proposed which are based on four types of performance criteria and test the effect of firm strategies on its performance. According to the first hypothesis: there is a relationship between sales growth and return on equity. In order to test the first secondary hypothesis, this model has been used:

Table 4: Results of the First Secondary Hypothesis Test

\begin{tabular}{lrrrr}
\hline \multicolumn{1}{c}{ Variable } & $\beta$ & $\begin{array}{r}(\beta \\
\text { Coefficient }\end{array}$ & t Statistics & P-Value \\
\hline Constant Value & $\alpha$ & $\mathbf{0} / \mathbf{3 8 6}$ & $\mathbf{3 2 / 6 5}$ & $\mathbf{0} / \mathbf{0 0 0}$ \\
Sales Growth & $\beta_{1}$ & $\mathbf{0 / 1 9 5}$ & $5 / 07$ & $\mathbf{0} / \mathbf{0 0 0}$ \\
& & & $=\mathrm{Adj}^{2} \mathbf{0} / \mathbf{1 0 9} \mathrm{R}^{2}=\mathbf{0} / \mathbf{1 4 1}$ \\
Total Regression & Statistics & P-Value & The coefficient of determination and the \\
Model & $\mathrm{F}$ & & $\begin{array}{r}\text { adjusted coefficient of determination } \\
\end{array}$ \\
\hline
\end{tabular}

Based on the results of the first secondary hypothesis test presented in Table 4, the significance level of $\mathrm{F}$ Statistics (0.000) is below the acceptable level of error (5 percent) and the whole of the regression model is significant. Based on the insignificance of (P-value) t-statistics of an acceptable level of error for coefficient $\beta_{1}$, the results of the test indicated that sales growth has a significant and positive impact on return on equity. Therefore, the first hypothesis of the study cannot be rejected at the confidence level of $95 \%$. The coefficient of determination and the adjusted coefficient of determination also indicate that the variable entered in the regression model can explain $14 \%$ of the variability of the dependent variable. According to the second secondary hypothesis there is a relationship between sales growth and free cash flow per share. To test the second hypothesis, the following model is used:

Table 5: Results of the Second Secondary Hypothesis Test

\begin{tabular}{lrrcr}
\hline \multicolumn{1}{c}{ Variable } & $\beta$ & $\begin{array}{r}(\beta \\
\text { Coefficient }\end{array}$ & t Statistics & P-Value \\
\hline Constant Value & $\alpha$ & $-78 / 86$ & $-12 / 62$ & $\mathbf{0} / \mathbf{0 0 0}$ \\
Sales Growth & $\beta_{1}$ & $-20 / 46$ & $-1 / 003$ & $\mathbf{0} / \mathbf{3 1 6}$ \\
Total Regression & $\mathrm{F}$ & P-Value & The coefficient of determination and the \\
Model & Statistics & $\mathbf{0 / 3 1 6}$ & adjusted coefficient of determination \\
\hline
\end{tabular}

Based on the results of the second secondary hypothesis test presented in Table 5, the significance level of $\mathrm{F}$ Statistics (0.316) is below the acceptable level of error (5 percent) and the whole of the regression model is not significant. Based on the insignificance of (P-value) t-statistics of an acceptable level of error for coefficient $\beta_{1}$, the results of the test indicate that sales growth has no impact on free cash flow per share. 
Therefore, the second hypothesis of the study cannot be rejected at the confidence level of $95 \%$. The coefficient of determination and the adjusted coefficient of determination also indicate that the independent variable entered in the regression model cannot explain the variability of the dependent variable. According to the third secondary hypothesis there is a relationship between sales growth and return on assets. To test the third hypothesis, the following model is used:

Table 6: Results of the Third Secondary Hypothesis Test

\begin{tabular}{|c|c|c|c|c|c|}
\hline Variable & $\beta$ & $\begin{array}{r}(\beta \\
\text { Coefficient }\end{array}$ & & t Statistics & P-Value \\
\hline Constant Value & $\alpha$ & $0 / 142$ & & $26 / 866$ & $0 / 000$ \\
\hline Sales Growth & $\beta_{1}$ & $0 / 088$ & \multirow{2}{*}{\multicolumn{3}{|c|}{$\begin{array}{rr}5 / 111 & \mathbf{0} / \mathbf{0 0 0} \\
= & \operatorname{AdjR}^{2} \mathbf{0} / \mathbf{0 4 1} \mathrm{R}^{2}=\mathbf{0} / \mathbf{4 1 0}\end{array}$}} \\
\hline \multirow{2}{*}{$\begin{array}{l}\text { Total Regression } \\
\text { Model }\end{array}$} & $\begin{array}{r}\mathrm{F} \\
\text { Statistics }\end{array}$ & P-Value & & & \\
\hline & $26 / 120$ & $0 / 000$ & \multicolumn{3}{|c|}{$\begin{array}{l}\text { The coefficient of determination and } \\
\text { the adjusted coefficient of } \\
\text { determination }\end{array}$} \\
\hline
\end{tabular}

Based on the results of the third secondary hypothesis test presented in Table 5-3, the significance level of $\mathrm{F}$ Statistics (0.000) is below the acceptable level of error (5 percent) and the whole of the regression model is significant. Based on the insignificance of (P-value) t-statistics of an acceptable level of error for coefficient $\beta_{1}$, the results of the test indicate that sales growth has a significant and positive impact on return on assets. Therefore, the third hypothesis of the study cannot be rejected at the confidence level of $95 \%$. The coefficient of determination and the adjusted coefficient of determination also indicate that the independent variable entered in the regression model can explain $4 \%$ of the variability of the dependent variable. According to the fourth secondary hypothesis there is a relationship between sales growth and free cash flow for the firm. To test the fourth hypothesis, the following model is used:

Table 7: Results of the Fourth Secondary Hypothesis Test

\begin{tabular}{lrrrr}
\hline \multicolumn{1}{c}{ Variable } & $\beta$ & Coefficient $(\beta$ & t Statistics & P-Value \\
\hline Constant Value & $\alpha$ & $-0 / 153$ & $-9 / 935$ & $\mathbf{0} / \mathbf{0 0 0}$ \\
Sales Growth & $\beta_{1}$ & $-/ 020$ & $\begin{array}{c}-0 / 404 \\
=\mathrm{Adj}^{2} \mathbf{0} / \mathbf{0 0 0} \mathrm{R}^{2}=\mathbf{0} / \mathbf{1 6 0}\end{array}$ \\
$\begin{array}{l}\text { Total Regression } \\
\text { Model }\end{array}$ & F Statistics & P-Value & $\begin{array}{r}\text { The coefficient of determination } \\
\text { and the adjusted coefficient of } \\
\text { determination }\end{array}$ \\
\hline
\end{tabular}

Based on the results of the fourth secondary hypothesis test presented in Table 7, the significance level of $\mathrm{F}$ Statistics (0.000) is above the acceptable level of error (5 percent) and the whole of the regression model is not significant. Based on the significance of (P-value) t-statistics of an acceptable level of error for coefficient $\beta_{1}$, the results of the test indicate that sales growth has no impact on free cash flow for firm. Therefore, the forth hypothesis of the study cannot be rejected at the confidence level of $95 \%$. The coefficient of determination and the adjusted coefficient of determination also indicate that the independent variable entered in the regression model can explain the variability of the dependent variable. According to the fifth secondary hypothesis there is a relationship between liquidity and return on equity. To test the sixth hypothesis, the following model is used:

Based on the results of the fifth secondary hypothesis test presented in Table 8, the significance level of $\mathrm{F}$ Statistics (0.000) is below the acceptable level of error (5 percent) and the whole of the regression model is significant. Based on the insignificance of (P-value) t-statistics of an acceptable level of error for coefficient $\beta_{1}$, the results of the test indicate that liquidity has a significant and positive impact on return on equity. Therefore, the fifth hypothesis of the study cannot be rejected at the confidence level of $95 \%$. The coefficient of determination and the adjusted coefficient of determination also indicate that the independent variable entered in the regression model can explain $11 \%$ of variability of the dependent variable. 
Table 8: Results of the Fifth Secondary Hypothesis Test

\begin{tabular}{lrrrr}
\hline \multicolumn{1}{c}{ Variable } & $\beta$ & $\begin{array}{r}(\beta \\
\text { Coefficient }\end{array}$ & t Statistics & P-Value \\
\hline Constant Value & $\alpha$ & $0 / 393$ & $31 / 344$ & $\mathbf{0} / \mathbf{0 0 0}$ \\
Liquidity & $\beta_{1}$ & $0 / 469$ & $3 / 586$ & $\mathbf{0} / \mathbf{0}$ \\
& $\mathrm{F}$ & $\mathrm{P}-$ Value & $=\mathrm{Adj}^{2} \mathbf{0} / \mathbf{1 0 2} \mathrm{R}^{2}=\mathbf{0} / \mathbf{1 2 1}$ \\
$\begin{array}{l}\text { Total Regression } \\
\text { Model }\end{array}$ & & & \\
& $\mathbf{1 2 / 8 6 2}$ & $\mathbf{0} / \mathbf{0 0 0}$ & $\begin{array}{r}\text { The coefficient of determination and the } \\
\text { adjusted coefficient of determination }\end{array}$
\end{tabular}

According to the sixth secondary hypothesis there is a relationship between liquidity and free cash flow per share. To test the sixth hypothesis, the following model is used:

Table 9: Results of the Sixth Secondary Hypothesis Test

\begin{tabular}{|c|c|c|c|c|}
\hline Variable & $\beta$ & $\begin{array}{r}(\beta \\
\text { Coefficient }\end{array}$ & t Statistics & P-Value \\
\hline Constant Value & $\alpha$ & $-89 / 54$ & $-13 / 682$ & $0 / 000$ \\
\hline Liquidity & $\beta_{1}$ & $118 / 84$ & $1 / 709$ & $0 / 048$ \\
\hline $\begin{array}{l}\text { Total Regression } \\
\text { Model }\end{array}$ & $\begin{array}{r}F \\
\text { Statistics } \\
\mathbf{2} / \mathbf{9 2 2}\end{array}$ & $\begin{array}{r}\text { P-Value } \\
\mathbf{0 / 0 4 8}\end{array}$ & $\begin{array}{l}\text { The coefficient of } \\
\text { adjusted }\end{array}$ & $\begin{array}{l}=\operatorname{Adj} R^{2} \mathbf{0} / 053 R^{2}=\mathbf{0} / \mathbf{0 5 5} \\
\text { determination and the } \\
\text { oefficient of determination }\end{array}$ \\
\hline
\end{tabular}

Based on the results of the sixth secondary hypothesis test presented in Table9, the significance level of F Statistics (0.048) is below the acceptable level of error (5 percent) and the whole of the regression model is significant. Based on the insignificance of (P-value) t-statistics of an acceptable level of error for coefficient $\beta_{1}$, the results of the test indicate that liquidity has a significant and positive impact on free cash flow per share. Therefore, the sixth hypothesis of the study cannot be rejected at the confidence level of $95 \%$. The coefficient of determination and the adjusted coefficient of determination also indicate that the independent variable entered in the regression model can explain $5.5 \%$ of variability of the dependent variable. According to the seventh secondary hypothesis there is a relationship between liquidity and return on assets. To test the seventh hypothesis, the following model is used:

Table 10: Results of the Seventh Secondary Hypothesis test

\begin{tabular}{lrrrr}
\hline \multicolumn{1}{c}{ Variable } & $\beta$ & Coefficient $(\beta$ & t Statistics & P-Value \\
\hline Constant Value & $\alpha$ & $\mathbf{0} / \mathbf{1 2 5}$ & $23 / 685$ & $\mathbf{0} / \mathbf{0 0 0}$ \\
Sales Growth & $\beta_{1}$ & $\mathbf{0 / 5 2 5}$ & $9 / 510$ & $\mathbf{0} / \mathbf{0 0 0}$ \\
\multirow{2}{*}{ Total Regression } & $\mathrm{F}$ & $\mathrm{P}$-Value & The coefficient of determination and the & $=\mathrm{AdjR}^{2} \mathbf{0} / \mathbf{1 2 8} \mathrm{R}^{2}=\mathbf{0} / \mathbf{1 2 9}$ \\
Model & Statistics & $\mathbf{0 / 0 0 0}$ & adjusted coefficient of determination \\
\hline
\end{tabular}

Based on the results of the seventh secondary hypothesis test presented in Table10, the significance level of $F$ Statistics (0.000) is below the acceptable level of error (5 percent) and the whole of the regression model is significant. Based on the insignificance of (P-value) t-statistics of an acceptable level of error for coefficient $\beta_{1}$, the results of the test indicate that liquidity has a significant and positive impact on return on assets. Therefore, the first hypothesis of the study cannot be rejected at the confidence level of $95 \%$. The coefficient of determination and the adjusted coefficient of determination also indicate that the variable entered in the regression model can explain $13 \%$ of variability. According to the eighth secondary hypothesis there is a relationship between liquidity and free cash flow for firm. To test the eighth hypothesis, the following model is used: 
Table 11: Results of the First Secondary Hypothesis Test

\begin{tabular}{lrrrr}
\hline \multicolumn{1}{c}{ Variable } & $\beta$ & Coefficient $(\beta$ & t Statistics & P-Value \\
\hline Constant Value & $\alpha$ & $-0 / 167$ & $-10 / 309$ & $0 / 000$ \\
Liquidity & $\beta_{1}$ & $0 / 190$ & $1 / 126$ & $0 / 260$ \\
Total Regression & $\mathrm{F}$ & P-Value & The coefficient of determination and the \\
Model & Statistics & $\mathbf{2 . 9 0 8}$ & $0 / 260$ & adjusted coefficient of determination \\
\hline
\end{tabular}

Based on the results of the eighth secondary hypothesis test presented in Table11, the significance level of $\mathrm{F}$ Statistics (0.260) is higher than the acceptable level of error (5 percent) and the whole of the regression model is not significant. Based on the significance of (P-value) t-statistics of an acceptable level of error for coefficient $\beta_{1}$, the results of the test indicate that Liquidity has no impact on free cash flow for firm. Therefore, the eighth hypothesis of the study cannot be rejected at the confidence level of $95 \%$. The coefficient of determination and the adjusted coefficient of determination also indicate that the independent variable entered in the regression model cannot explain the variability of the dependent variable.

The second main hypothesis: there is a relationship between capital structure and firm performance. To test the second hypothesis, the four secondary hypotheses have been provided which are based on four performance criteria and considers the test of the effect of corporate capital structure on its performance. According to the first hypothesis, there is a relationship between debt ratio and return on equity. To test the first hypothesis, the following model is used:

Table12: Results of the first secondary hypothesis test

\begin{tabular}{|c|c|c|c|c|c|}
\hline Variable & $\beta$ & Coefficient $(\beta$ & & t Statistics & P-Value \\
\hline Constant Value & $\alpha$ & $0 / 373$ & & $12 / 216$ & $0 / 000$ \\
\hline Debt ratio & $\beta_{1}$ & $0 / 084$ & & $0 / 741$ & $0 / 082$ \\
\hline $\begin{array}{l}\text { Total Regression } \\
\text { Model }\end{array}$ & $\begin{array}{r}F \\
\text { Statistics } \\
\mathbf{3 . 0 3 0} \\
\end{array}$ & $\begin{array}{r}\text { P-Value } \\
\mathbf{0 / 0 8 2}\end{array}$ & The & $\begin{array}{r}\text { coefficient of } \\
\text { adjusted }\end{array}$ & $\begin{array}{l}=\operatorname{AdjR}^{2} \mathbf{0} / \mathbf{0 0 3} \mathrm{R}^{2}=\mathbf{0} / \mathbf{0 0 5}^{2} \\
\text { determination and the } \\
\text { coefficient of determination }\end{array}$ \\
\hline
\end{tabular}

Based on the results of the first secondary hypothesis test presented in Table 12, the significance level of $\mathrm{F}$ Statistics (0.082) is above the acceptable level of error (5 percent) and the whole of the regression model is not significant at the significance level of 95\%. Based on the significance of (P-value) t-statistics of an acceptable level of error for coefficient $\beta_{1}$, the results of the test indicated that debt ratio has no impact on return on equity at the confidence level of $95 \%$. The coefficient of determination and the adjusted coefficient of determination also indicate that the independent variable entered in the regression model can explain 5\% of variability of the dependent variable.

a) The second secondary hypothesis: there is a relationship between debt ratio and free cash flow per share. To test the second hypothesis, the following model is used:

Which is acceptable (5 percent) and total regression model is not significant at the level 95\% is not significant. Based on the significance of (P-value) t-statistics of an acceptable level of error for coefficient $\beta_{1}$, the results of the test indicated that debt ratio has no impact on free cash flow per share. Therefore, the second hypothesis of the study cannot be accepted at the confidence level of $95 \%$. The coefficient of determination and the adjusted coefficient of determination also indicate that the independent variable entered in the regression model cannot explain the variability of the dependent variable. 
Table 13: Results of the second secondary hypothesis test

\begin{tabular}{lllll}
\hline Variable & $\boldsymbol{\beta}$ & $\boldsymbol{\beta}$ Coefficient & t Statistics & P-Value \\
\hline Constant Value & $\alpha$ & $-75 / 54$ & $824 / 4-$ & $0 / 000$ \\
Debt ratio & $\beta_{1}$ & $-95 / 24$ & $-0 / 383$ & $0 / 702$ \\
\multirow{2}{*}{ Total Regression } & $\mathrm{F}$ & & $0 / 000000 \mathrm{R}^{2}=0 /=\mathrm{Adj}^{2}$ \\
Model & Statistics & P-Value & The coefficient of determination and the \\
& 0.146 & $0 / 702$ & adjusted coefficient of determination \\
\hline
\end{tabular}

b) There is a relationship between debt ratio and return on assets.

To test the third hypothesis, the following model is used:

Table 14: Results of the third secondary hypothesis test

\begin{tabular}{|c|c|c|c|c|}
\hline Variable & $\beta$ & ( $\beta$ Coefficient & t Statistics & P-Value \\
\hline Constant Value & $\alpha$ & 0.261 & $20 / 087$ & $0 / 000$ \\
\hline Debt Ratio & $\beta_{1}$ & $-0 / 169$ & $-8 / 228$ & $0 / 000$ \\
\hline $\begin{array}{l}\text { Total Regression } \\
\text { Model }\end{array}$ & $\begin{array}{l}\text { F } \\
\text { Statistics } \\
67 / 708\end{array}$ & $\begin{array}{l}\text { P-Value } \\
0 / 000\end{array}$ & \multicolumn{2}{|c|}{$\begin{array}{l}\qquad=A d j R^{2} 0 / 099 R^{2}=0 / 100 \\
\text { The coefficient of determination and the } \\
\text { adjusted coefficient of determination }\end{array}$} \\
\hline
\end{tabular}

Based on the results of the third secondary hypothesis test presented in Table 14, the significance level of $\mathrm{F}$ Statistics (0.000) is below the acceptable level of error (5 percent) and the whole of the regression model is significant at the level 5\%. Based on the insignificance of (P-value) t-statistics of an acceptable level of error for coefficient $\beta_{1}$, the results of the test indicated that debt ratio has a significant and negative impact on corporate assets. Therefore, the third secondary hypothesis of the study cannot be rejected at the confidence level of 95\%. The coefficient of determination and the adjusted coefficient of determination also indicate that the variable entered in the regression model can explain $1 \%$ of variability of the dependent variable. According to the fourth secondary hypothesis there is a relationship between debt ratio and free cash flow for firm.

To test the fourth hypothesis, the following model is used:

Table 15: Results of the third secondary hypothesis test

\begin{tabular}{|c|c|c|c|c|}
\hline Variable & $\boldsymbol{\beta}$ & ( $\beta$ Coefficient & t Statistics & P-Value \\
\hline Constant Value & $\alpha$ & $-0 / 230$ & $-5 / 890$ & $0 / 000$ \\
\hline Debt ratio & $\beta_{1}$ & $0 / 125$ & $023 / 2$ & $0 / 000$ \\
\hline $\begin{array}{l}\text { Total Regression } \\
\text { Model }\end{array}$ & $\begin{array}{l}\mathrm{F} \\
\text { Statistics } \\
4 / 094\end{array}$ & $\begin{array}{l}\text { P-Value } \\
0 / 043\end{array}$ & \multicolumn{2}{|c|}{$\begin{array}{l}\qquad=\operatorname{Adj}^{2} 0 / 007 \mathrm{R}^{2}=0 / 082 \\
\text { The coefficient of determination and the } \\
\text { adjusted coefficient of determination }\end{array}$} \\
\hline
\end{tabular}

Based on the results of the fourth secondary hypothesis test presented in Table 15, the significance level of $F$ Statistics (0.043) is below the acceptable level of error (5 percent) and the whole of the regression model is significant at the level 95\%. Based on the insignificance of (P-value) t-statistics of an acceptable level of error for coefficient $\beta_{1}$, the results of the test indicated that debt ratio has a significant and positive impact on free cash flow for firm. Therefore, the first hypothesis of the study cannot be rejected at the confidence level of $95 \%$. The coefficient of determination and the adjusted coefficient of determination also indicate that the variable entered in the regression model can explain $8 \%$ of variability of the dependent variable.

\section{Conclusion}

Independent variable sales growth has a significant positive impact on return on equity and return on assets, i.e. by increase in the amount of sale growth, return on equity and return on assets increase. This indicates that the firms with a higher sales growth have a higher return on equity and return on asset, and by decrease in the amount of sales growth, return on equity and return on assets decrease. As we know, return on equity 
and return on assets are considered to be as profitability ratios; it is better to say whenever a net benefit for the performance evaluation of a formula is used, the evaluation of the profitability of the company is assumed. Therefore, based on the results of the present study, a firm with a high sales growth has a high profitability as well. The liquidity as an independent variable has a significant positive impact on return on equity, return on assets, and free cash flow per share. It means that a firm with higher liquidity has a more improved performance. If liquidity of a firm increases, free cash flow per share increases and a high free cash flow per share indicate that profit per share must be increased, because free cash flow per share is an indicator to measure change in profit per share, and is regarded to be a signal of firm's ability to pay debts, cash profit, share redemption and business facilities.

Debt ratio as an independent variable has a significant impact on free cash flow for firm and return on assets, which this has a positive impact on free cash flow for firm and a negative impact on return on assets. After confirming four secondary hypotheses formulated for main secondary hypothesis test, two third and fourth secondary hypotheses are also confirmed. It could be concluded that by increase in debt ratio, free cash flow for firm increase and return on assets decreases. Using this ratio, the total amount of contributions provided through debts can be calculated. This ratio is used as an indicator to determine firm financial risk, because using non-equity resources increases the likelihood of firm disability in repayment of loans. Therefore, lenders and credit institutions pay special attention to this issue. If these organizations feel that the firm applying for loan has a high debt ratio may cancel the loan or demand additional collateral .It could be concluded that by increase in debt ratio, assets created by debts and also free cash flow per share decrease, because firms to pay their debt use their cash surpluses, and so return on assets increase.

\section{Suggestions}

A) Analysts and those active in capital market pay attention to sales growth, firm liquidity, debt ratio and also profitability criteria when they attempt to consider firm performance.

B) It is better investors consider the negative significant impact of debt ratio on return on assets and also consider the significant impact of sales growth and liquidity on firm performance.

C) The validity lending institutions pay attention to negative significant impact of debt ratio on return on assets when granting credit to firms

D) Firm managers pay attention to significant positive impact of liquidity and return on equity and also the significant negative impact of debt ratio on return on assets.

\section{References}

Anvari, R. A. A., Tehrani, R. \& Seraji, H. (2004). The relationship between economic value added, earnings before interest and tax, and cash flows from operating activities with the stock market value of listed companies in Tehran Stock Exchange. Accounting and Auditing Reviews, 37, 3-21.

Kaplan, R. \& Norton, D. (1996). The balanced scorecard. Harvard Business Press.

Khalili, D. B., Rafieian, M. M., Hejazi, S. H., Yusefi, H. A., Yektaian, N. \& Shirani-Bidabadi, L. (2011). Effect of Achillea millefolium, Artemisia absinthium \&amp; Juglans regia leaves extracts on Trichomonas vaginalis, in vitra. Journal of Shahrekord University of Medical Sciences, 12, 62-69.

Li, K., Yue, L. \& Zhao, T. (2009). Ownership, Institutions, and Capital Structure: Evidence from China.

Manian, A., Mousikhani, M. \& Jamporazmi, M. (2009). The relationship between IT alignment and business, and organizational performance in active firms of information technology, using structural equations model. Journal of Information Technology Management, 1(3), 89-106

Malekian E. \& Asghari, J. (2006). Studying the relationship between economic value added and rate of return on assets in order to evaluate the performance of Iranian Companies listed on the Stock Exchange. NYSE, 54(55), 24-33.

Mires, G., Williams, F. \& Howie, P. (2001). Randomized controlled trial of cardiotocography versus Doppler auscultation of the fetal heart at admission in labor in low risk obstetric population. British Medical Journal, 322, 1457-1462

Miller, M. \& Modigliani, F. (1961). Dividend policy, growth and the valuation of shares. Journal of Business, 34, 411-33. 
Miller, M. \& Rock, R. (1985). Dividend policy under asymmetric information. Journal of Finance, 40, 10311051.

Modigliani, F. \& Miller, M. (1958). The Cost of Capital, Corporate Finance and the Theory of Investment. American Economic Review, 48, 261-297.

Muneer, S., Butt, B. Z. \& Rehman, K. U. (2011). A Multifactor Model of Banking Industry Stock Returns: An Emerging Market Perspective. Information Management and Business Review, 2(6), 267-275

Muneer, S. \& Rehman, S. U. (2012). Materialization of Behavioral Finance and Behavioral Portfolio Theory: A Brief Review. Journal of Economics and Behavioral Studies, 4(8), 431-435

Muneer, S., Rehman, S. U. \& Butt, B. Z. (2013). Dividend Signaling Power on Organizations' Future Earnings: a Brief Review of Dividend Theories. Actual Problems of Economics, 3(141), 380-387.

Muneer, S., Iqbal, S. M. J., Jahanzeb, A. \& Rehman, S. U. (2012). A Critical Review of Capital Structure Theories. Information Management and Business Review, 4(11), 553-557

Ong, S. T., Teo, L. C., \& The, H. B. (2011). Analysis on Financial Performance and Efficiency Changes of Malaysian Commercial Banks after Mergers and Acquisitions. International Journal of Business and Management Tomorrow, 1(2), 1-16.

Rajatavanin, R. \& Venkatesh, S. (2007). Current practices of corporate finance in Thailand. 20th Australasian Finance and Banking Conference 2007.

Saeed, A. (2009). Formality of Financial Sources and Firm Growth: Empirical Evidence from Brazilian SMEs 1999-2005. Journal of Academic Research in Economics, 1(2), 131-144.

Setaiesh, M. H. \& Kashanipoor, F. (2010). Factors influencing the capital structure of listed companies listed in Tehran Stock Exchange. Financial Research, 12(30). 